\title{
Role of the oblique ligament in the integrity of the medial collateral ligament of the canine elbow joint
}

\author{
[Papel do ligamento oblíquo na integridade do ligamento colateral medial da \\ articulação do cotovelo de cães] \\ D. Oliveira ${ }^{1}$, S.M. Baraldi-Artoni ${ }^{2 *}$, A.C. Shimano ${ }^{3}$, J.R. Rossi ${ }^{2}$, M.C.H. Tovar ${ }^{2}$ \\ ${ }^{1}$ Universidade Federal Rural de Pernambuco - Garanhuns, PE \\ ${ }^{2}$ Faculdade de Ciências Agrárias e Veterinárias - UNESP \\ Via de Acesso Prof. Paulo Donato Castellane, s/n \\ 14884-900 - Jaboticabal, SP \\ ${ }^{3}$ Faculdade de Medicina de Ribeirão Preto - USP - Ribeirão Preto, SP
}

\begin{abstract}
It was studied the arrangement of the collagen fibrils of the medial collateral ligament of the canine elbow joint and evaluated its diameter, when it was isolated or associated to the oblique ligament and loaded in tension until failure. Eighteen joints were divided in three groups. The first group had the medial collateral ligament collected and not loaded, the second group had the medial collateral ligament tested separately and the third group had both ligaments associately tested. Medial collateral ligament not submitted to strain presented a wavy and reticular pattern of the collagen fibers, which was not totally destroyed when it was loaded associated to the oblique ligament, and totally loses the reticular pattern when stretched separately. When the medial collateral ligament was loaded in tension separately, the mean collagen fibrils diameter increased in relation to the group not submitted to the tensile strain. Associated to the oblique ligament, the mean collagen fibrils diameter was the largest in the insertion area and the smallest in the mid-substance, in relation to the other groups. It was concluded that the oblique ligament could favor the integrity of the medial collateral ligament insertion area, facilitating its reconstruction after lesion with larger efficiency.
\end{abstract}

Keywords: dog, medial collateral ligament, oblique ligament, elbow, collagen fibrils

\section{RESUMO}

Foram estudados o arranjo e o diâmetro médio das fibrilas colágenas do ligamento colateral medial da articulação do cotovelo do cão, isolado ou associado ao ligamento oblíquo e tracionado até a ruptura. Dezoito articulações foram divididas em três grupos. O primeiro grupo teve o ligamento colateral medial coletado, mas não tracionado; o segundo grupo teve o ligamento colateral medial tracionado isoladamente; o terceiro grupo teve os ligamentos colateral medial e obliquo tracionados associadamente. O ligamento colateral medial não submetido ao ensaio de tração apresentou um padrão ondulado das fibras colágenas, o qual não foi totalmente destruido quando foi tracionado, associado ao ligamento oblíquo, e perdeu totalmente o padrão reticular das fibras colágenas quando testado isoladamente. Quando o ligamento colateral medial foi submetido à tensão isoladamente, o diâmetro médio das fibrilas colágenas aumentou em relação ao grupo não submetido à tensão. Associado ao ligamento oblíquo, o diâmetro médio das fibrilas colágenas foi o maior na região de inserção e o menor na região média, em relação aos outros grupos. Concluiu-se que o ligamento oblíquo pode favorecer a integridade da região de inserção do ligamento colateral medial, aumentando a eficácia de sua reconstrução após a lesão.

Palavras-chave: cão, ligamento colateral medial, ligamento oblíquo, cotovelo, fibrilas colágenas

Recebido em 9 de maio de 2005

Aceito em 5 de dezembro de 2006

*Autor para correspondência (corresponding author)

E-mail: smbart@fcav.unesp.br 


\section{Oliveira et al.}

\section{INTRODUCTION}

Oliveira et al. (2003) described the medial collateral ligament of the canine elbow joint as divided in cranial and caudal portions. The caudal portion is longer and narrower and penetrates the interosseous space, attaching to the proximal caudolateral surface of the radius caudally to the insertion of the cranial portion of the lateral collateral ligament.

The oblique ligament is capsular and also becomes separated in cranial and caudal portions. The cranial portion attaches to the proximal medial border of the radius, bypassing the tendons of insertion of the brachial muscle and biceps brachii muscle. The cranial portion of the medial collateral ligament fuses with the caudal portion of the oblique ligament (Oliveira et al., 2003). In this transition area between the two ligaments, the collagen fibers form a right angle, suggesting the relationship of the medial collateral ligament and the oblique ligament and reinforcing the biomechanics of these ligaments (Oliveira, 2002).

The ligaments and tendons are characterized, according to Benjamin and Ralphs (1998), for the great strain they support. They are predominantly formed by collagen fibers. More than $90 \%$ of ligament collagen, according to Frank et al. (1985), is type I. According to Bloomberg (1995), the ligaments consist of connective tissue, composed by water, types I and III collagen, several proteoglycans, little elastin and several other biochemical substances. Proteoglycans interact with the collagen in vitro and in vivo, probably due to electrostatic binding of acidic groups of the proteoglycans to the basic radicals of collagen (Junqueira et al., 1980).

The collagen fibrils of fibrous connective tissues present two different aspects consistently related to their anatomical site: a "straight" arrangement, mainly found in the large, parallel fibrils of tendons and ligaments, and a "helical" arrangement present in small, wavy fibrils often gathered in sinuous bundles or tri-dimensional networks and associated with cells and elastic fibres in blood vessel walls, intersticial tissues and sheaths (Raspanti et al., 1990). An important fact in tendons and ligaments is the crimp pattern of collagen fibers disposition observed in a longitudinal section. This disposition makes it possible to act as a sort of "shock absorber" by which slight ligament elongation is allowed to occur without damage to its fibers (Frank et al., 1985; Benjamin and Ralphs, 1997). Frank et al. (1985) also described this wavy pattern seen in histologic sections for the cells (fibroblasts) and for the matrix.

Liao and Belkoff (1999), using the knee medial collateral ligament of rabbits, created a failure model for ligaments which assumes that sequential uncrimping and stretching of collagen fibers is responsible for the mechanical response of ligament. Ligament tested in vitro with unidirectional, longitudinal tensile loading exhibits nonlinear mechanical behavior, as reported by Frank et al. (1985). In other words, the collagen fibers are gradually stretched, lose their wavy pattern, until that all are in the maximum limit of traction and begin the failure.

Viidik and Ekholm (1968) observed in a scanning electron microscopy study that the collagen fibers wavy pattern vanishes at relatively low loads. Yahia et al. (1990) made a similar experiment and calculated in $10 \%$ the maximum strain for mechanical stimulation of ligaments, before the fibers of smaller diameter were broken.

Several authors related the mechanical function of collagen tissues and their diameters distribution of the collagen fibrils. Hart et al. (1992) studying the transmission electron micrographs of anterior cruciate and medial collateral knee ligaments of rabbits, verified that the variation of the mean fibril diameters for these ligaments were significantly different comparing others areas of each, as well as among different animals.

The contribution of the ligaments to the elbow stability is a product of the knowledge of the morphology and the biomechanical parameters which is fundamental for the maintenance of the integrity of the soft tissues that compose the elbow (Regan et al., 1991; Vogelsang et al., 1997). As the artroplasty is also developed for the use in dogs, it is necessary to know the anatomical characteristics and the functional properties of the ligaments of this species in full detail for the correct intervention (Vogelsang et al., 1997).

Considering the contiguity of the caudal portion of the oblique ligament and the cranial portion of the canine elbow medial collateral ligament, the objective of this study was to analyze the alterations of the medial collateral ligament diameter and disposition of the collagen fibers, when it was associated or not to the oblique ligament and submitted to tensile load. 


\section{MATERIAL AND METHODS}

Nine medium-sized adult mongrel dogs (five males and four females) were studied. The animals averaged $16.2 \mathrm{~kg}$ of weight, were clinically healthy and did not present any history of locomotor affection. They were donated by the Centro de Pesquisas Parasitológicas (CPPar) of UNESP Jaboticabal, SP. After euthanasia (processed through anesthetic overdose with $25 \mathrm{mg} / \mathrm{kg}$ of sodic pentobarbital $^{1}$ associated with endovenous administration of potassium chloride), fresh right and left thoracic limbs were dissecated, and the joints constituted by the humerus, radius, ulna with medial collateral (Fig. 1A) and oblique (Fig. 1B) ligaments were collected.

The proximal portion of the ulna was removed by making a transverse osteotomy through the bone at the level of mid-trochlear notch (Fig. 1D). The joints were divided in three groups, group one $(n=6)$ the medial collateral ligament was collected and not loaded, group two $(n=6)$ the medial collateral ligament was loaded separately (the oblique ligament was severed) and in the group three $(n=6)$ both ligaments (medial collateral + oblique) were loaded in tension associately.

The joints submitted to the tensile load were placed in a tensile testing apparatus ${ }^{2}$ of the Laboratório de Bioengenharia - Faculdade de Medicina de Ribeirão Preto,USP. The bones were rigidly fixed, using clamps. Bone-ligament-bone preparations were placed in the testing apparatus (Fig. 1C) and tractioned in a rate of $10 \mathrm{~mm} / \mathrm{min}$, with tension from $0.5 \mathrm{kgf}$ to $80 \mathrm{kgf}$ until its rupture.

The proximal region and the mid-substance of the medial collateral ligament of all groups were collected for analysis of the collagen fibrils disposition and diameter. It was taken as proximal region the area adjacent to the proximal insertion of the ligament and the mid-substance as the area that includes the rupture region.

The samples were carefully sliced along the long axis of the ligaments. The prefixation of the fragments was made in $3 \%$ glutaraldehyde in $0.1 \mathrm{M}$ phosphate buffer for 36 hours and then post-fixed in $1 \%$ osmium tetroxide for 3 hours. Later, the samples were dehydrated in increasing concentrations of ethanol in intervals of 10 minutes for each passage. For scanning electron microscopy half of the samples were dried by the critical point

\footnotetext{
${ }^{1}$ Thiopental $^{\circledR}$

${ }^{2}$ EMIC $^{\circledR}$
}

drying method using liquid $\mathrm{CO}_{2}$, followed by evaporation of gold-palladium. The samples were then examined in a scanning electron microscope ${ }^{3}$.

For the transmission electron microscopy, after the dehydration, half of the fragments were embedded ${ }^{4}$ for 24 hours at room temperature and after at $60^{\circ} \mathrm{C}$ for 72 hours. The samples were then cut into thin transverse sections, using an ultramicrotome ${ }^{5}$, with diamond knives, stained with $1 \%$ uranyl acetate and lead citrate, and examined under a transmission electron microscope ${ }^{6}$.

Images of transverse sections of the collagen fibrils were obtained from the transmission electron microscope. Using an analyzing system of images ${ }^{7}$, the perimeter of 30 aleatory fibrils was surrounded of 10 images of each experimental group, and the diameter of the collagen fibrils was determined automatically.

The numerical data obtained were statistically analyzed using analysis of variance and the Tukey's test by the software Statistic Analysis System (User's..., 1985). Summary results are presented as mean \pm SD

\section{RESULTS AND DISCUSSION}

The medial collateral ligament fibers loaded in tension came more straighten than the unstretched fibers. When the medial collateral ligament was tested associated to the oblique ligament, the loss of the wavy pattern was smaller than the group of the isolated medial collateral ligament. Yahia et al. (1990) mentioned that before reaching the rupture limit, the collagen fiber under strain elongates progressively and permanently and it loses the undulating pattern (crimp). This fact was also observed by Viidik and Ekholm (1968) in tendons of rabbits.

Oliveira (2002) related the possible reinforcement that the oblique ligament could give to the medial collateral ligament, due to the right angle that these ligament collagen fibers form. The association of collagen fibers into bundles determines the architectural organization of the connective tissues and conditions their mechanical properties. The structure and the function of these tissues are most certainly related to the biosynthetic activity of the cells that produce chemically defined structural components (Lapiere et al., 1977).

\footnotetext{
${ }^{3}$ Jeol JSM-5410

${ }^{4}$ Araldite ${ }^{\circledR}$

${ }^{5}$ Leica ${ }^{\circledR}$

${ }^{6}$ Jeol JEM-1010

7 software Media Cybernetics ${ }^{\circledR}$
} 

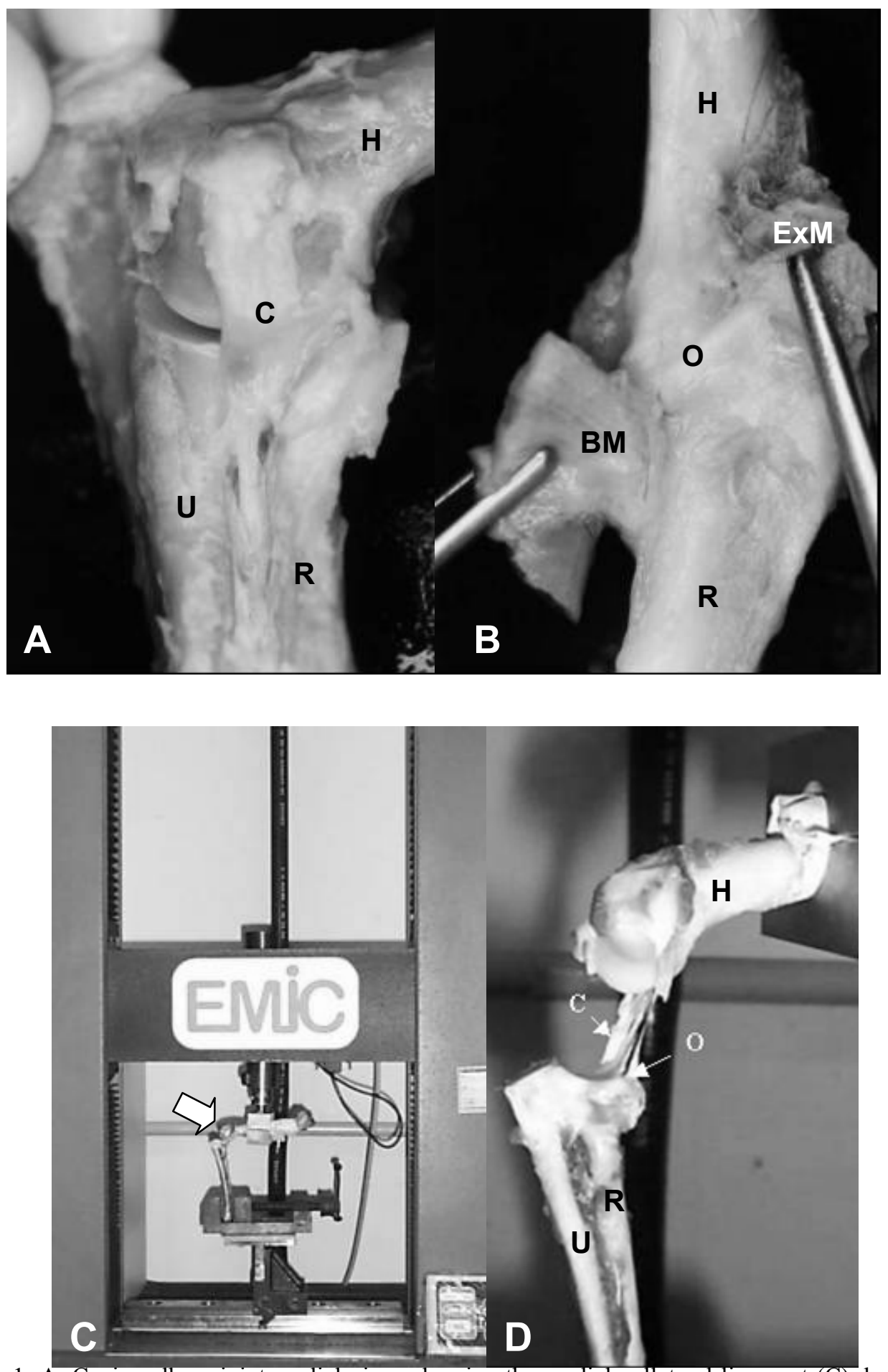

Figure 1. A. Canine elbow joint medial view, showing the medial collateral ligament (C), humerus $(\mathrm{H})$, radius $(\mathrm{R})$ and ulna $(\mathrm{U})$ before olecranon osteotomy. B. Canine elbow joint cranial view with oblique ligament $(\mathrm{O})$ and the muscles around it (m. extensor carpi radialis and $m$. extensor digitorum comunis ExM; $m$. biceps brachii and $m$. brachialis - BM). C. Canine elbow joint (white arrow) in the testing apparatus $\left(\mathrm{EMIC}^{\circledR}\right)$ in tensile loading. D. Detail of the canine elbow joint during the tensile test, showing the ligament rupture. Note the olecranon osteotomy $(\mathrm{C}$ - medial collateral ligament; $\mathrm{O}-$ oblique ligament; $\mathrm{H}$ - humerus; $\mathrm{R}$ - radius; $\mathrm{U}$ - ulna) 
The unstretched medial collateral ligament (Fig. 2A) observed by scanning electron microscopy presented a reticular pattern of the collagen, which was not totally destroyed in the ligaments loaded in tension associated to the oblique ligament (Fig. 2B). When tested separately, the medial collateral ligament after strain totally loses the reticular pattern, demonstrating the waste of the fibers to resist to the tension (Fig. 2C). Strocchi et al. (1992) studying the human anterior cruciate ligament, observed wavy bundles of collagen fibers arrayed in various directions, which can provide a structure able to withstand the multiaxial stresses and varying tensile strains imposed upon it. Frank et al. (1985) reported that ligaments tested in vitro, loaded in unidirectional tension exhibit a nonlinear mechanical behavior, for multifactorial reasons. During the stretching, an increasing number of ligament fibers would be recruited into tension, protecting the ligament against a total and immediate breaking. The authors also related that the ligaments exhibit a mechanism of "memory", by responding slightly differently to each stretch in a series and being able to return to prestretch lengths in order to reduce the stress on the ligament. That mechanism of memory is highly complex and almost certainly involves a complicated interaction of matrix elements, including collagen, water, glycosaminoglycans and elastin, when it is present (Frank et al., 1985).

Mean fibril diameter of the medial collateral ligament proximal to region tested associated to the oblique ligament $(60 \pm 10 \mathrm{~nm})$ was superior $(\mathrm{P}<0.01)$ in relation to the other analyzed groups (Table 1). In contrast, the fibrils of the medial collateral ligament mid-substance associated to the oblique ligament presented the smallest diameter in relation to the other groups $(34 \pm 6 \mathrm{~nm})$ (Fig. 2E). The heterogeneity of the collagen fibrils diameter of the medial collateral ligament not submitted to tensile failure test was similar to the rat Wistar flexor digitorum profundus tendon, as Raspanti et al. (1990) studied. Several authors have been proposed the correlation among the mechanical function of collagen tissues and the distribution of the diameters of the collagen fibrils (Strocchi et al., 1992; Benjamin and Ralphs, 1997). Montes and Junqueira (1991) reported that the structures where the type I collagen is described through electron microscopy technique, it comes packed conditioned, formed by thick collagen fibrils of variable diameters, with an evident staining pattern, unlike the type III collagen fibrils, which are dispersed and with more uniform diameters. Parry et al. (1978) mentioned that after tension, the capacity of the tissue to return to its initial pattern is due to the bimodal distribution of the fibrils or the presence of the appropriate fibril type for that function.

The bimodality of the collagen fibrils of the medial collateral ligament not submitted to tensile failure is reflected in the low mean diameter found $(37 \pm 5 \mathrm{~nm})$ (Table 1; Fig. 2D), in relation to the ligaments that were submitted to the tensile failure. Collagen fibrils diameter of the canine medial collateral ligament are within the interval of measures of the previous study about human ligament (Strocchi et al., 1992).

Table 1. Mean ( $\pm \mathrm{SD}$, in nanometers) collagen fibril diameters of the unstretched medial collateral ligament (UMCL) and loaded in tension until failure with (MCLO) or without (MCL) the oblique ligament in the canine elbow joint. Fibrils of the proximal region (prox) and mid-substance (mid) of the medial collateral ligaments were evaluated $(\mathrm{n}=18)$

\begin{tabular}{|l|c|}
\hline Group & Diameter $(\mathrm{nm})$ \\
\hline prox UMCL & $37 \pm 5 \mathrm{a}$ \\
\hline mid UMCL & $37 \pm 5 \mathrm{a}$ \\
\hline prox MCLO & $60 \pm 10 \mathrm{~b}$ \\
\hline mid MCLO & $34 \pm 6 \mathrm{c}$ \\
\hline prox MCL & $45 \pm 6 \mathrm{~d}$ \\
\hline mid MCL & $44 \pm 6 \mathrm{~d}$ \\
\hline
\end{tabular}

$\mathrm{a}, \mathrm{b}, \mathrm{c}, \mathrm{d}=$ same letters mean no statistical differences between the groups $(\mathrm{P}>0.01)$

When the medial collateral ligament was submitted to the tensile failure test, the mean diameter of the proximal and mid-substance fibrils had a relative increase in the proximal region $(45 \pm 6 \mathrm{~nm})$ and in the mid-substance $(44 \pm 6 \mathrm{~nm})$ (Table 1). Although it was not statistically significant in relation to the non tested ligament, due to the decrease of the amount of fibrils of smaller diameter, which have smaller resistance to the tensile load (Fig. 2F). Montes and Junqueira (1991) reported that the structures where the type I collagen is described through electron microscopy technique, it comes packed conditioned, formed by thick collagen fibrils of variable diameters, with an evident staining pattern, unlike the type III collagen fibrils, which are dispersed and with more uniform diameters. Parry et al. (1978) mentioned that after tension, the capacity of the tissue to return to its initial pattern is due to the bimodal distribution of the fibrils or the presence of the appropriate fibril type for that function. 

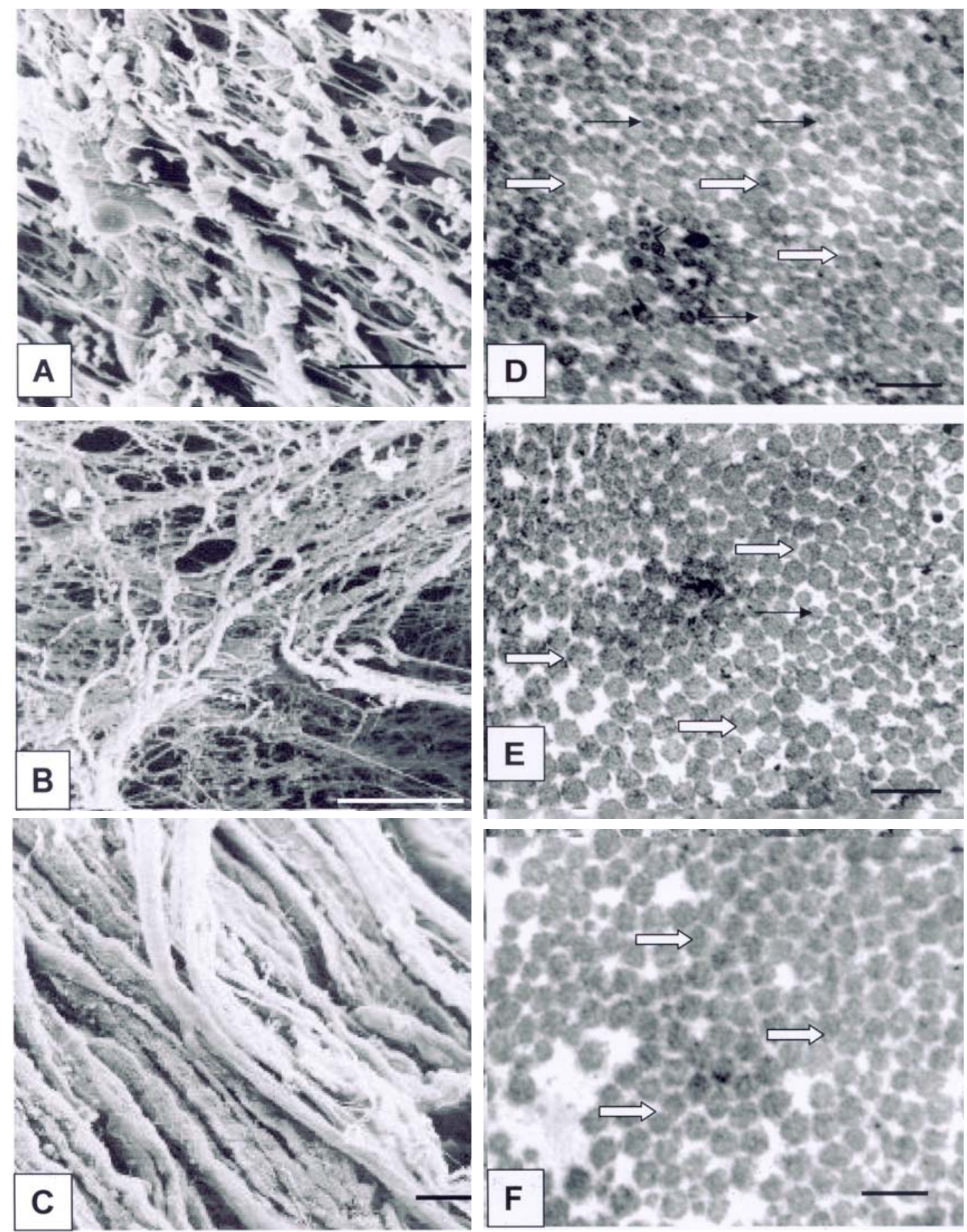

Figure 2. Electron micrographs of the mid-substance of the medial collateral ligament collagen fibers of the canine elbow joint. $\mathbf{A}$ and $\mathbf{D}$. Unstretched collagen fibrils; $\mathbf{B}$ and $\mathbf{E}$. Medial collateral ligament collagen fibrils loaded at failure with the oblique ligament in the joint; $\mathbf{C}$ and $\mathbf{F}$. Medial collateral ligament collagen fibrils loaded at failure isolated in the joint. A and $\mathbf{B}$. Scanning electron microscopy showing the reticular pattern of the medial collateral ligament collagen fibers. Barr $=25000 \mathrm{~nm}$. C. The collagen fibers become more linear when oblique ligament is ruptured. Barr=25000nm. D and $\mathbf{E}$. Transverse sections of the collagen fibrils from the medial collateral ligament by transmission electron microscopy. Note the bimodal collagen fibrils distribution (thin arrow - small diameter fibril; white arrow - large diameter fibril). Barr=100nm. F. Predominance of large diameter collagen fibril after tension when the oblique ligament is not present in the joint. Barr $=100 \mathrm{~nm}$. 
The medial collateral ligament loaded in tension in the presence of the oblique ligament presented isolation of the larger diameter fibrils in the proximal region and smaller diameter fibrils kept in the rupture area (mid-substance), data statistically significant (Table 1). This behavior could protect the insertion area, preventing the avulsion of bony insertion and demonstrating the oblique ligament importance in the integrity of the medial collateral ligament insertion areas. This observation confirms the results of Vogelsang et al. (1997) that noticed the lateral and medial collateral ligaments of the canine elbow just failed within their mid-substance and did not occur avulsion of bony insertion of the tested specimens.

It was concluded that the oblique ligament could have an important role in the stability of the canine elbow joint, as it favors the integrity and it increases the resistance to tensile load of the medial collateral ligament. Besides, when the oblique ligament is intact, present in joint, the medial collateral ligament collagen fibers suffer smaller alteration in the architecture of these fibers after rupture, and could be reconstructed with superior efficiency after lesion.

\section{REFERENCES}

BENJAMIN, M.; RALPHS, J.R. Fibrocartilage in tendons and ligaments - an adaptation to compressive load. J. Anat., v. 193, p. 481-494, 1998.

BENJAMIN, M.; RALPHS, J.R. Tendons and ligaments - an overview. Histol. Histopathol., v. 12, p. 1135-1144, 1997.

BLOOMBERG, M.S. Tendon, muscle and ligament injuries and surgery. In: AMSTEAD, M.L. Small animal orthopedics. St. Louis: Mosby, 1995. p. 488530 .

FRANK, C.; AMIEL, D.; WOO, S.L.Y. et al. Normal ligament properties and ligament healing. Clin. Orthop. Rel. Res., v. 196, p. 15-25, 1985.

HART, R.A.; WOO, S.L.Y.; NEWTON, P.O. Ultrastructural morphometry of anterior cruciate and medial collateral ligaments: An experimental study in rabbits. J. Orthop. Res., v. 10, p. 96-103, 1992.

JUNQUEIRA, L.C.U.; BIGNOLAS, G.; MOURÃO, P.A.S. et al. Quantitation of collagen-proteoglycan interaction in tissue sections. Connect. Tiss. Res., v. 7, p. $91-96,1980$.
LAPIERE, M.; NUSGENS, B.; PIERARD, G.E. Interaction between collagen type I and type III in conditioning bundles organization. Connect. Tiss. Res., v. 5, p. 21-29 1977.

LIAO, H.; BELKOFF, S.M. A failure model for ligaments. J. Biomech., v. 32, p. 183-188, 1999.

MONTES, G.S.; JUNQUEIRA, L.C.U. The use of the picrosirius-polarization method for the study of the biopathology of collagen. Mem. Inst. Oswaldo Cruz, v. 86, p. $1-11,1991$

OLIVEIRA, D. Aspectos morfométricos e histológicos dos ligamentos colateral medial e oblíquo da articulação do cotovelo do cão (Canis familiaris). 2002. 54f. Dissertação (Mestrado em Cirurgia Veterinária) - Faculdade de Ciências Agrárias e Veterinárias, Universidade Estadual Paulista, Jaboticabal, SP.

OLIVEIRA, D.; BARALDI-ARTONI, S.M.; ORSI, A.M. et al. Morphometric study of the medial collateral and oblique ligaments of the elbow joint of the dog (Canis familiaris). Int. J. Morphol., v. 21, p. 23-28, 2003.

PARRY, D.A.D.; BARNES, G.R.G.; CRAIG, A.S. A comparison of the size distribution of collagen fibrils in connective tissues as a function of age and a possible relation between fibril size distribution and mechanical properties. Proc. R. Soc. London, v. 203, p. $305-321,1978$.

RASPANTI, M.; OTTANI, V.; RUGGERI, A. Subfibrillar architecture and functional properties of collagen: a comparative study in rat tendons. J. Anat., v. 172 , p. $157-164,1990$.

REGAN, W.D.; KORINEK, S.L.; MORREY, B.F. et al. Biomechanical study of ligaments around the elbow joint. Clin. Orthop. Rel. Res., v. 271, p. 170-179, 1991.

STROCCHI, R.; PASQUALE, V.; GUBELLINI, P. et al. The human anterior cruciate ligament: histological and ultrastructural observations. J. Anat., v. 180, p. 515-519, 1992.

USER'S guide: Statistics. Cary, NC: SAS Institute, 1985. 956p.

VIIDIK, A.; EKHOLM, R. Light and electron microscopic studies of collagen fibers under strain. $Z$. Anat. Entwickl., v. 127, p. 154-164, 1968.

VOGELSANG, R.L.; VASSEUR, P.B.; PEAUROI, J.R. et al. Structural, material and anatomic characteristics of the collateral ligaments of the canine cubital joint. Am. J. Vet. Res., v. 58, p. 461-466, 1997.

YAHIA, L.; BRUNET, J.; LABELLE, S. et al. A scanning electron microscopic study of rabbit ligaments under strain. Matrix, v. 10, p. 58-64, 1990. 